\title{
IS SEMI-FLOCCULATION EFFECTIVE AS \\ PRETREATMENT TO ULTRAFILTRATION IN \\ WASTEWATER TREATMENT?
}

\author{
H. K. Shon ${ }^{1}$, S. Vigneswaran ${ }^{1 *}$, H. H. Ngo ${ }^{1}$, and R. Ben Aim ${ }^{2}$ \\ ${ }^{1}$ Faculty of Engineering, University of Technology, Sydney, P.O. Box 123, Broadway, \\ NSW 2007, Australia \\ ${ }^{2}$ Institute National des Sciences Appliquees, Complexe Scientifique de Rangueil, 31077 \\ Toulouse Cedex 4, France \\ * The author to whom all the correspondence should be addressed (Tel.: 61295142641, Fax: 61295142633). \\ Email: s.vigneswaran@uts.edu.au
}

\begin{abstract}
In this study, ferric chloride $\left(\mathrm{FeCl}_{3}\right)$ flocculation was used as a pretreatment to ultrafiltration (UF) in treating synthetic wastewater containing synthetic organic matter (SOM). The effect of flocculant dose was studied in terms of organic removal and membrane flux decline.
\end{abstract}


The UF with optimum dose of $\mathrm{FeCl}_{3}\left(68 \mathrm{mg} \mathrm{L}^{-1}\right)$ did not experience any flux decline during the whole operation of 6 hours. The preflocculation with a smaller dose of $20 \mathrm{mg} \mathrm{L}^{-1}$ of $\mathrm{FeCl}_{3}$ led to a severe flux decline in the UF (more than $65 \%$ in 6 hours). To understand the phenomenon of the flux decline of UF, the MW ranges of SOM removed by different doses of $\mathrm{FeCl}_{3}$ and by the post treatment of UF were studied. Flocculation with at least $50 \mathrm{mg} \mathrm{L}^{-1}$ of $\mathrm{FeCl}_{3}$ dose was found to be necessary to avoid any significant flux decline and to obtain superior DOC removal.

Keywords: flocculation, molecular weight distribution, pretreatment, synthetic organic matter, ultrafiltration

\section{INTRODUCTION}

Membrane processes such as ultrafiltration (UF), nanofiltration (NF) and reverse osmosis (RO) are successfully used in wastewater treatment, especially in water reuse applications. One of the major drawbacks of membrane processes is the membrane fouling by organic contaminants (Lin et al., 1999). Effective pretreatment is an efficient way of reducing membrane fouling.

Conventional sewage treatment includes primary treatment to remove the majority of suspended solids, secondary biological treatment to degrade the biodegradable dissolved organics and nitrogen, and tertiary to remove most of the remaining organic and inorganic 
solids and pathogenic microorganisms. The presence of organic pollutant in water and wastewater has been the cause of public concern in past decades due to their potential health hazard (Wang et al., 2001; Imai et al., 2002). Effluent organic matter (EfOM) in the biological treated wastewater consists of mixed particulates and soluble substance, which is combined with natural organic matter (NOM) from drinking water and soluble microbial product (SMP) from biological treatment. EfOM can thus be broadly classified into three different groups by their origins i.e. 1) refractory NOM derived from drinking water sources, 2) synthetic organic compounds (SOC) produced during domestic use and disinfection byproducts (DBPs) generated during disinfection processes of water and wastewater treatment and 3) SMP derived during biological processes of wastewater treatment (Drewes and Fox, 1999).

Many researchers found that flocculation is one of the most effective pretreatment methods to remove EfOM (Abdessemed and Nezzal, 2002; Abdessemed et al., 2002; Shon et al., 2004; Kim et al., 2002). Abdessemed and Nezzal (2002) observed that flocculation with $\mathrm{FeCl}_{3}$ removed $77 \%$ of COD in wastewater. They also found that flocculation increased the permeate flux by $46.6 \%$. Shon et al. (2004) showed that $\mathrm{FeCl}_{3}$ flocculation removed $68 \%$ of organic matter (in terms of DOC) from the biologically treated wastewater. The majority of organics removed were the ones with the large molecular weight (MW). AlMalack and Anderson (1996) determined the optimum coagulation conditions for wastewater. It was $200 \mathrm{mg} \mathrm{L}^{-1} \mathrm{FeCl}_{3}$ at a $\mathrm{pH}$ of 9. The $\mathrm{COD}$ removal with this optimum dose of $\mathrm{FeCl}_{3}$ was $99.3 \%$. According to the results of Aguiar et al. (1996), the optimum dose of coagulant was $2.1 \pm 0.2 \mathrm{mg}$ Fe per mg of total organic carbon (TOC). 
It may not be economical to use large doses of flocculants. Larger chemical doses will also lead to larger quantity of chemical sludge. Therefore, it is advisable to use as smaller dose of flocculent as possible to achieve significant organic removal that can lead to minimum membrane fouling in the post treatment of membrane filtration. Thus, in this study, the effect of flocculant dose was studied in terms of organic removal and membrane flux decline. The performance of flocculation as pretreatment and UF as post treatment was also studied for their ability to remove organic matter of different MW.

\section{EXPERIMENTAL}

\subsection{Synthetic wastewater}

This study was carried out with synthetic wastewater. The composition of the synthetic wastewater is presented in Table 1. This synthetic wastewater represents effluent organic matter (EfOM) generally found in the biologically treated sewage effluent (BTSE) (Seo et al., 1997). Tannic acid, peptone, sodium lignin sulfornate, sodium lauryle sulfate and arabic acid represent larger MW portion, while peptone, beef extract and humic acid consist of organic matters of smaller MW. 


\subsection{Synthetic organic matter (SOM) characterization}

\subsubsection{Dissolved organic carbon (DOC)}

DOC was measured by using the Dohrmann Phoenix 8000 UV-persulphate TOC analyzer with an autosampler. All samples were filtered through $0.45 \mu \mathrm{m}$ membrane prior to the DOC measurement. This is the reason the values are given in terms of DOC instead of TOC.

\subsubsection{Molecular weight (MW) distribution}

The synthetic wastewater after flocculation with different doses and after UF was subjected to MW distribution measurements. High pressure size exclusion chromatography (HPSEC, Shimadzu Corp., Japan) with a SEC column (Protein-pak 125, Waters Milford, USA) was used to determine the MW distributions of organic matter. Standard polystyrene sulfonates (PSS: 210, 1800, 4600, 8000, and 18000 daltons) were used to calibrate the equipment. All samples were filtered through $0.45 \mu \mathrm{m}$ membrane prior to the measurement. Details of the measurement methodology are given elsewhere (Her, 2002 and Cho, 1998). 


\subsection{Experimental set-up of partial flocculation and filtration}

Figure 1 presents experimental schematic of flocculation and UF unit. The flocculation was carried out with a range of ferric chloride $\left(\mathrm{FeCl}_{3}\right)$ doses from $20 \mathrm{mg} \mathrm{L}^{-1}$ to $68 \mathrm{mg} \mathrm{L}^{-1}$. The samples were stirred rapidly for 1 minute at $100 \mathrm{rpm}$, followed by 20 minutes of slow mixing at $30 \mathrm{rpm}$, and 30 minutes of settling. The supernatant then underwent UF.

In this study, the cross flow ultrafiltration unit (Nitto Denko, Corp.) was used to study the organic removal from synthetic wastewater. The synthetic wastewater after undergoing flocculation was pumped to the membrane module (effective membrane area $0.006 \mathrm{~m}^{2}$; flat sheet configuration). The operating pressure and cross-flow velocity were controlled at $300 \mathrm{kPa}$ and $0.5 \mathrm{~m} / \mathrm{s}$ by means of by-pass and regulating valves. The Reynold's number and shear stress at the wall were 735.5 and $5.33 \mathrm{~Pa}$, respectively. The membrane used in this study was NTR 7410 (Nitto Denko Corp., Japan) (Table 2).

\section{RESULTS AND DISCUSSION}

\subsection{Removal of DOC by partial $\mathrm{FeCl}_{3}$ flocculation}

The removal of synthetic organic matter (SOM) from the wastewater by ferric chloride $\left(\mathrm{FeCl}_{3}\right)$ flocculation and by the post treatment of UF was investigated in terms of DOC removal (Figure 2). DOC removal was the highest (78.2\%) with the $\mathrm{FeCl}_{3}$ flocculation at a 
dose of $68 \mathrm{mg} \mathrm{L}^{-1}$. The optimum $\mathrm{FeCl}_{3}$ dose was found to be $68 \mathrm{mg} \mathrm{L}^{-1}$ from the Jar test experiments. Experiments were also conducted with reduced concentrations of $\mathrm{FeCl}_{3}$ (semi optimum doses) followed by UF in order to study the effect of semi flocculation on DOC removal. For example, the DOC removal from wastewater was $87.8 \%$ with preflocculation (68 $\mathrm{mg} \mathrm{L}^{-1}$ of $\mathrm{FeCl}_{3}$ ) and post UF application. The removal efficiency reduced when lower doses of $\mathrm{FeCl}_{3}$ were employed. Although the semi flocculation (with reduced $\mathrm{FeCl}_{3}$ doses) led to less pretreatment removal efficiency, the post treatment of UF compensated the total net removal i.e. $82.8 \%$ (with $40 \mathrm{mg} \mathrm{L}^{-1}$ of $\mathrm{FeCl}_{3}$ ) and $82.2 \%$ (with $20 \mathrm{mg} \mathrm{L}^{-1}$ of $\mathrm{FeCl}_{3}$ ). In other words, the post treatment of UF after $68 \mathrm{mg} \mathrm{L}^{-1} \mathrm{FeCl}_{3}$ flocculation removed only $9.6 \%$ of additional DOC removal, whereas that after $20 \mathrm{mg} \mathrm{L}^{-1} \mathrm{FeCl}_{3}$ flocculation removed $48.2 \%$ of additional DOC removal. Thus, the semi flocculation as pretreatment delegated the majority of organic removal to UF.

\subsection{Flux decline of UF with pretreated waste water}

The flux decline of UF in treating synthetic wastewater was studied in terms of normalized permeate flux $\left(\mathrm{J} / \mathrm{J}_{0}\right)$. It was studied both with and without the pretreatment of $\mathrm{FeCl}_{3}$ flocculation at different doses (Figure 3). The flux decline $\left(\mathrm{J} / \mathrm{J}_{0}\right)$ with no pretreatment was at 0.68 after 6 hours of UF operation. After the pretreatment of flocculation with the optimum dose of $\mathrm{FeCl}_{3}\left(68 \mathrm{mg} \mathrm{L}^{-1}\right)$, the UF did not experience any flux decline. It may be due to the removal of the majority of SOM by flocculation and complexation (Shon et al., 2004a). However, the preflocculation with partial optimum dose of $\mathrm{FeCl}_{3}$ led to significant flux decline. For example, the preflocculation with $20 \mathrm{mg}$ 
$\mathrm{L}^{-1}$ of $\mathrm{FeCl}_{3}$ led to a flux decline $\left(\mathrm{J} / \mathrm{J}_{0}\right)$ in the post treatment of UF of $65 \%$ in 6 hours. This indicates that flocculant dose should be sufficient enough to avoid or minimize the flux decline.

\subsection{Molecular weight (MW) distribution}

To understand the phenomenon of the flux decline, it is necessary to know the types of organics and/or the range of MW distribution of SOM removed from the wastewater by flocculation and ultrafiltration. This will help in the selection of suitable pretreatment method and a correct membrane for the given application (Tandanier et al., 2000). Synthetic wastewater has a number of known compounds at a known concentration. Hence, the MW distribution of each component in SOM in synthetic wastewater was first analyzed (Figure 4). The MW of the mixed synthetic wastewater ranged from 291 daltons to about 34118 with the highest fraction of $943-1196$ daltons. Although sodium lignin sulfornate and tannic acid showed the peaks at 12120 and 6343 daltons respectively, the corresponding peaks were not found in the mixed synthetic wastewater (Figure 4 (c)). It may be due to aggregations between SOM and inorganic and/or organic compounds in the synthetic wastewater.

Figure 5 describes the MW distribution of UF effluent without any pretreatment and with preflocculation (using $\mathrm{FeCl}_{3}$ ). It should be noted that the settled flocs were removed after $\mathrm{FeCl}_{3}$ flocculation and only the supernatant underwent ultrafiltration. Flocculation with

larger doses (closer to the optimum dose) from $68 \mathrm{mg} \mathrm{L}^{-1}$ to $50 \mathrm{mg} \mathrm{L}^{-1} \mathrm{FeCl}_{3}$ removed 
practically all the large MW SOM such as tannic acid, sodium lignin sulfornate, sodium lauryle sulfate and arabic acid. The $\mathrm{FeCl}_{3}$ dose of $40 \mathrm{mg} \mathrm{L} \mathrm{L}^{-1}$ removed the majority of large MW SOM, but not all of them. Further, this preflocculation was also helpful to remove some of the small MW compounds (573 - 1002 daltons) such as peptone, beef extract and humic acid. However, the smallest MW range of compounds in the range of 248 daltons could not be removed by flocculation. The phenomenon of the small MW organic matter removal (573 daltons to 1002) by $\mathrm{FeCl}_{3}$ flocculation may be due to the complexation of $\mathrm{Fe}$ at wide range of $\mathrm{pH}$ (Vilge-Ritter et al., 1999). $\mathrm{FeCl}_{3}$ dose of $40 \mathrm{mg}$ $\mathrm{L}^{-1}$ and less did not remove all the large MW compounds and the majority of small $\mathrm{MW}$ compounds. The post treatment of UF with the pretreatment of flocculation removed practically the organic compounds of more than 1000 daltons.

Table 3 presents the weight-averaged MW of the compounds in the supernatant after different $\mathrm{FeCl}_{3}$ doses. The weight-averaged $\mathrm{MW}$ value of the influent was 29759 daltons, which was similar to the effluent after flocculation with $20 \mathrm{mg} \mathrm{L}^{-1}$ (around 29594 daltons).

A correlation between the amount of $\mathrm{FeCl}_{3}$ dose and the averaged-weight $\mathrm{MW}$ is presented in Figure 6. The deviant crease circle shows that the pretreatment of flocculation with reduced $\mathrm{FeCl}_{3}$ dose (less than the optimum dose) is possible as an adequate pretreatment to minimize the flux decline and to obtain high DOC removal. In the present study, a dose of $50 \mathrm{mg} \mathrm{L}^{-1}$ of $\mathrm{FeCl}_{3}$ was sufficient to run the UF with no (or minimum) flux decline and higher DOC removal. Here, it should be noted that the above finding and the quantitative values are true only for the synthetic wastewater used, as 
wastewater characteristics differ from area to area and from season to season. As such, one needs to conduct experiments with particular wastewater at the time of operation to determine the suitable dose of $\mathrm{FeCl}_{3}$.

\section{CONCLUSIONS}

A detailed experimental study was conducted to investigate the capability of semi flocculation as a pretreatment to UF. The organic matter (DOC) removal and the flux decline in the post treatment of UF were examined. These results were related to MW distribution of the effluent. The results obtained lead to the following conclusions.

1. Pretreatment of flocculation (with optimum $\mathrm{FeCl}_{3}$ dose of $68 \mathrm{mg} \mathrm{L}^{-1}$ ) removed $75 \%$ of DOC, which led to only $9.6 \%$ of additional DOC removal by the UF as post treatment. On the other hand, a partial $\mathrm{FeCl}_{3}$ dose of $20 \mathrm{mg} \mathrm{L}^{-1}$ removed only $34 \%$ of DOC and the UF removed another $48 \%$.

2. The flux decline (in terms of $J / J_{0}$ in the UF after 6 hours of operation) with no pretreatment was 0.68 . On the other hand, the UF with the preflocculation with the optimum dose of $\mathrm{FeCl}_{3}\left(68 \mathrm{mg} \mathrm{L}^{-1}\right)$ did not experience any flux decline during the operation of 6 hours. The preflocculation with sub-optimal doses of $\mathrm{FeCl}_{3}$ of $20-30 \mathrm{mg} \mathrm{\textrm {L } ^ { - 1 }}$ led to a significant flux decline, whereas a dose of $40-50 \mathrm{mg} \mathrm{L}^{-1}$ of $\mathrm{FeCl}_{3}$ showed only a minimum flux decline. 
3. The peaks corresponding to larger MW (36258 daltons) were not observed in the flocculated effluent with a $\mathrm{FeCl}_{3}$ dose of $50 \mathrm{mg} \mathrm{L}^{-1}$ and more. The effluent after flocculation with $\mathrm{FeCl}_{3}$ of less than $40 \mathrm{mg} \mathrm{L}^{-1}$ showed peaks corresponding to large MW.

4. The weight-averaged MW values of the compounds in the effluent after flocculation with more than $50 \mathrm{mg} \mathrm{L}^{-1} \mathrm{FeCl}_{3}$ was much lower (less than 700 daltons) as compared to the one with less than $40 \mathrm{mg} \mathrm{L^{-1 }} \mathrm{FeCl}_{3}$ (around 29000 daltons which is in the similar range of the influent).

The results showed that a $\mathrm{FeCl}_{3}$ dose of $50 \mathrm{mg} \mathrm{L}^{-1}$ was necessary to minimize the flux decline in the UF and to obtain higher DOC removal.

\section{ACKNOWLEDGEMENTS}

This research was funded by UTS research excellence grant (2003) and the Australian Research Council (ARC) discovery grant (2002 - 2003). The supports of the Kwangjeong Education Foundations for the scholarship and $\mu \mathrm{HM}$ laboratory in GIST for the analysis of molecular weight distribution are greatly appreciated. 


\section{REFERENCES}

Abdessemed, D. and Nezzal, G. (2002) Treatment of primary effluent by coagulationadsorption-ultrafiltration for reuse. Desalination 152 (1-3), 367-373.

Abdessemed, D., Nezzal, G. and Ben Aim, R. (2002) Fractionation of a secondary effluent with membrane separation. Desalination 146 (1-3), 433-437.

Aguiar, A., Lefebvre, E., Rahni, M. and Beguebe, B. (1996) Relationship between raw water TOC and the optimum coagulant dose (iron III chloride). Environmental Technology 17, 381-389.

Al-Malack, M.H. and Anderson, G.K. (1996) Coagulation-crossflow microfiltration of domestic wastewater. Journal of Membrane Science 121 (1), 59-65.

Cho, J. (1998) Natural organic matter (NOM) rejection by, and flux-decline of, nanofiltration (NF) and ultrafiltration (UF) membranes. Doctoral thesis of philosophy, University of Colorado. 6-7.

Drewes, J.E. and Fox P. (1999) Fate of natural organic matter (NOM) during groundwater recharge using reclaimed water. Water Science and Technology. 40 (9), 241-248.

Her, N.G. (2002) Identification and characterization of foulants and scalants on NF membrane, Doctoral thesis of philosophy. University of Colorado. 40 -49.

Imai, A., Fukushima, T., Matsushige, K. Kim, Y.H., Choi, K. (2002) Characterization of dissolved organic matter in effluents from wastewater treatment plants. Water Research. $36(6), 859-870$. 
Kim, S.L., Chen, J.P. and Ting, Y.P. (2002) Study on feed pretreatment for membrane filtration of secondary effluent. Separation and Purification Technology 29 (2), 171-179. Lin, C. F., Huang, Y. J. and Hao, O. J. (1999) Ultrafiltration processes for removing humic substances: effect of molecular weight fractions and PAC treatment. Water Research 33 (5), 1252-1264.

Seo, G.T., Ohgaki, S. and Suzuki, Y. (1997) Sorption characteristics of biological powdered activated carbon in BPAC-MF (biological activated carbon-microfiltration) system for refractory organic removal. Water Science and Technology 35 (7), 163-170.

Shon, H.K., Vigneswaran, S., Kim, In S., Cho, J., and Ngo, H.H. (2004a) The effect of pretreatment to ultrafiltration of biologically treated sewage effluent: a detailed effluent organic matter (EfOM) characterization. Water Research 38 (7), 1933-1939.

Tandanier, C.J., Berry, D.F. and Knocke, W.R. (2000) Dissolved organic matter apparent molecular distribution and number-average apparent molecular weight by batch ultrafiltration. Environmental Science \& Technology 34 (11), 2348-2353.

Vilge-Ritter, A., Rose, J., Masion, A., Bottero, J.Y. and Laine, J.M. (1999) Chemistry and structure of aggregates formed with Fe-salts and natural organic matter. Colloids and Surfaces 147 (3), 297-308.

Wang G.S., Chen H.W., Kang S.F. (2001) Catalyzed UV oxidation of organic pollutants in biologically treated wastewater effluents. The Science of the Total Environment. 277 (1-3), 87-94. 
Table 1 Constituents of the synthetic wastewater

Table 2 Characteristics of UF membrane used

Table 3 Weight-averaged MW values of the effluent samples after pretreatment (weightaveraged MW of initial $=29759$ daltons $)$ 
Table 1 Constituents of the synthetic wastewater

\begin{tabular}{lccc}
\hline \multicolumn{1}{c}{ Compound } & $\begin{array}{c}\text { Concentration } \\
\left(\mathbf{m g ~ L}^{-\mathbf{1}}\right)\end{array}$ & $\begin{array}{c}\text { Main molecular } \\
\text { weight (Daltons) }\end{array}$ & Fraction by DOC \\
\hline Beef extract & 1.8 & $298,145,65$ & 0.065 \\
Peptone & 2.7 & $34265,128,80$ & 0.138 \\
Humic acid & 4.2 & 1543,298 & 0.082 \\
Tannic acid & 4.2 & 6343 & 0.237 \\
Sodium lignin sulfonate & 2.4 & 12120 & 0.067 \\
Sodium lauryle sulphate & 0.94 & 34265 & 0.042 \\
Arabic gum powder $_{\text {Arabic acid (polysaccharide) }}$ & 4.7 & 925,256 & 0.213 \\
$\left(\mathrm{NH}_{4}\right)_{2} \mathrm{SO}_{4}$ & 5.0 & 38935 & 0.156 \\
$\mathrm{~K}_{2} \mathrm{HPO}_{4}$ & 7.1 & & 0 \\
$\mathrm{NH}_{4} \mathrm{HCO}_{3}$ & 7.0 & & 0 \\
$\mathrm{MgSO}_{4} \cdot 7 \mathrm{H}_{2} \mathrm{O}$ & 0.71 & & 0 \\
\hline
\end{tabular}


Table 2 Characteristics of UF membrane used

\begin{tabular}{ccccccc}
\hline Code & Material & $\begin{array}{c}\text { MWCO }^{*} \\
\text { (daltons) }\end{array}$ & $\begin{array}{c}\text { Contact } \\
\text { angle }\left(^{\circ}\right)\end{array}$ & $\begin{array}{c}\text { Zeta potential } \\
\text { at pH 7 }(\mathrm{mV})\end{array}$ & $\begin{array}{c}\mathrm{PWP}^{* *} \text { at } 300 \\
\mathrm{kPa}(\mathrm{m} / \mathrm{d})\end{array}$ & $\begin{array}{c}\mathrm{R}_{\mathrm{m}} \text { (membrane resistance, } \\
\left.\mathrm{x} 10^{12} \mathrm{~m}^{-1}\right)\end{array}$ \\
\hline $\begin{array}{l}\text { NTR } \\
7410\end{array}$ & polysulfones & 17,500 & 69 & -98.63 & 1.84 & 14.1 \\
\hline
\end{tabular}

\footnotetext{
* MWCO: molecular weight cut off

** PWP: pure water permeability
} 
Table 3 Weight-averaged MW values of the effluent samples after pretreatment (weightaveraged MW of initial $=29759$ daltons )

$\mathrm{FeCl}_{3}$ concentration

$68 \mathrm{mg} \mathrm{L}^{-1} \quad 60 \mathrm{mg} \mathrm{L}^{-1} \quad 50 \mathrm{mg} \mathrm{L}^{-1} \quad 40 \mathrm{mg} \mathrm{L}^{-1} \quad 30 \mathrm{mg} \mathrm{L}^{-1} \quad 20 \mathrm{mg} \mathrm{L}^{-1}$

\begin{tabular}{lllllll}
\hline MW & 517 & 584 & 685 & 26226 & 29324 & 29594
\end{tabular}

All units: Daltons 
Figure 1 Schematic drawing of partial flocculation and UF unit

Figure 2 DOC removal (a) by semi flocculation and (b) by semi flocculation followed by UF

Figure 3 Temporal variation of filtration flux of UF after a pretreatment of flocculation at different $\mathrm{FeCl}_{3}$ doses (NTR 7410 UF membranes, $\mathrm{J}_{0}=1.84 \mathrm{~m} / \mathrm{d}$ at $300 \mathrm{kPa}$; crossflow velocity $=0.5 \mathrm{~m} / \mathrm{s} ;$ MWCO of 17,500 daltons; Reynold's number: 735.5 ; shear stress: 5.33 $\mathrm{Pa})$

Figure $4 \mathrm{MW}$ distribution of SOM in the synthetic wastewater (a), b): individual components in the wastewater; c) wastewater (with all compounds mixed together)

Figure 5 MW distribution of the effluent of flocculation $\left(\mathrm{J}_{0}=1.84 \mathrm{~m} / \mathrm{d}\right.$ at $300 \mathrm{kPa}$; crossflow velocity $=0.5 \mathrm{~m} / \mathrm{s} ;$ MWCO $=17,500$ daltons; Reynold's number.: 735.5 ; shear stress: $5.33 \mathrm{~Pa}$; a) MW distribution of $\mathrm{SOM}$ with higher doses of $\mathrm{FeCl}_{3}(50-68 \mathrm{~m} / \mathrm{L})$; b) with $\mathrm{FeCl}_{3}$ of lower doses (40 - $20 \mathrm{mg} \mathrm{L}^{-1}$ flocculation); c) flocculation followed by $\mathrm{UF}$ Figure 6 Correlation between the $\mathrm{FeCl}_{3}$ concentrations and the corresponding weightaveraged MW values in the flocculated effluent. 


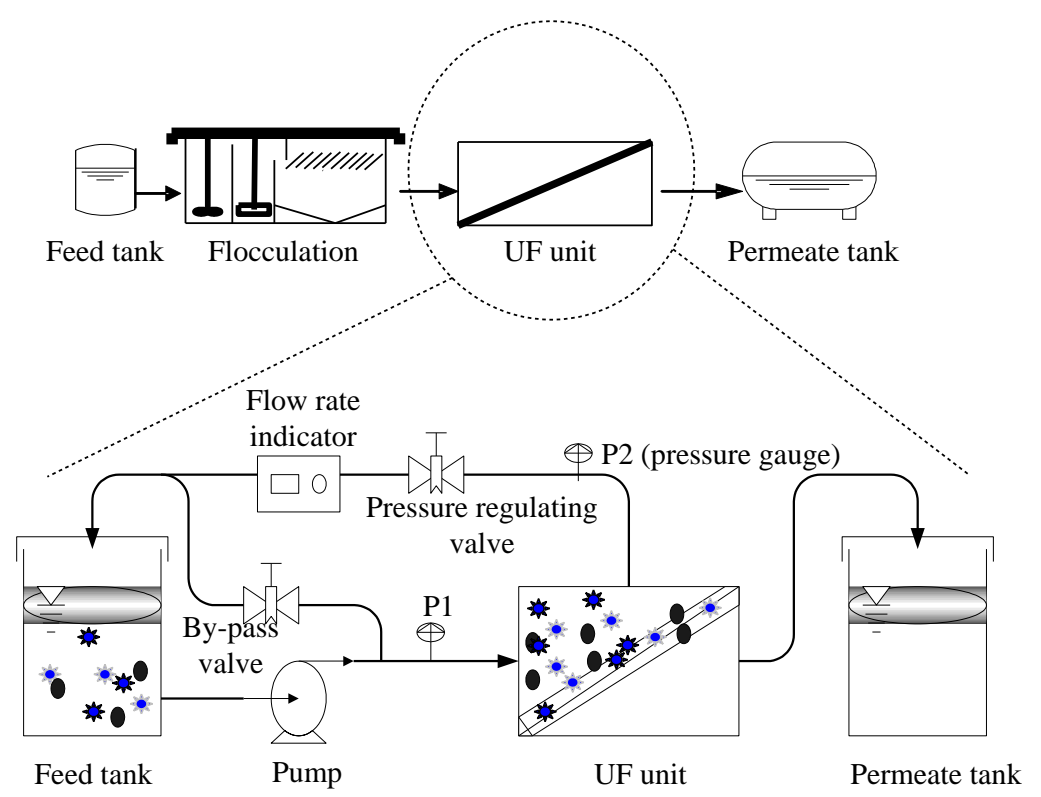

Figure 1 Schematic drawing of partial flocculation and UF unit 


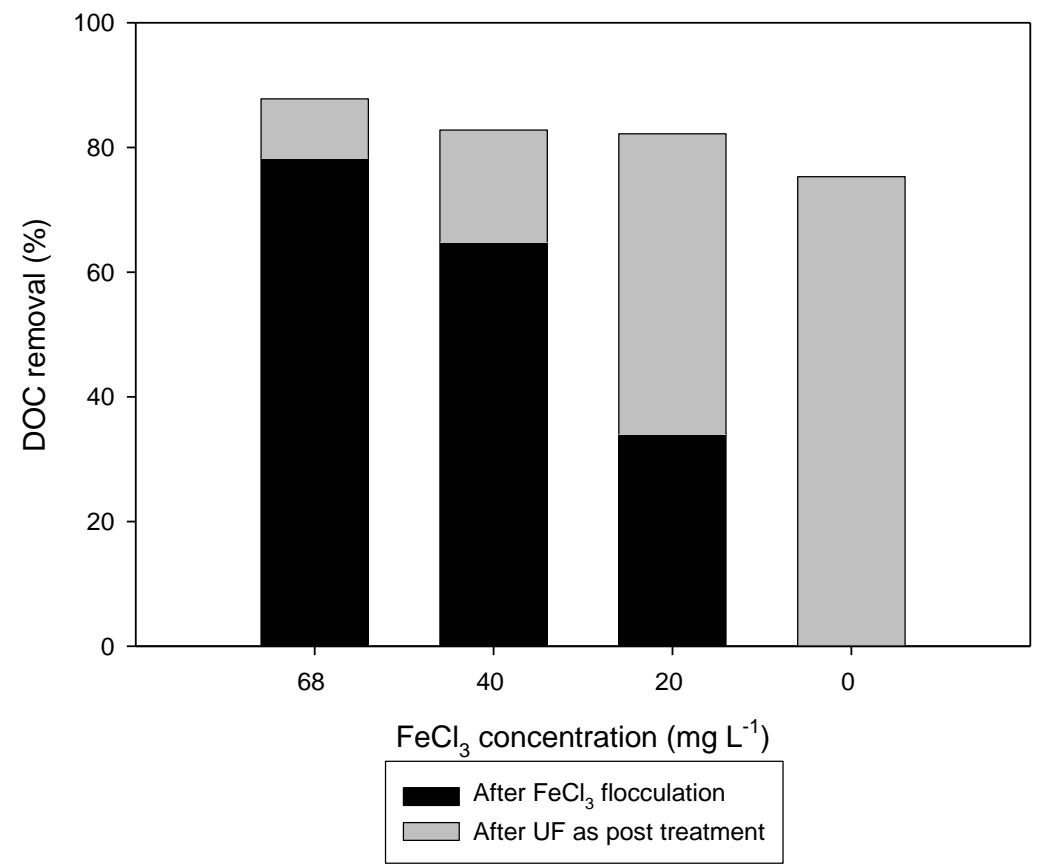

Figure 2 DOC removal by semi flocculation followed by UF 


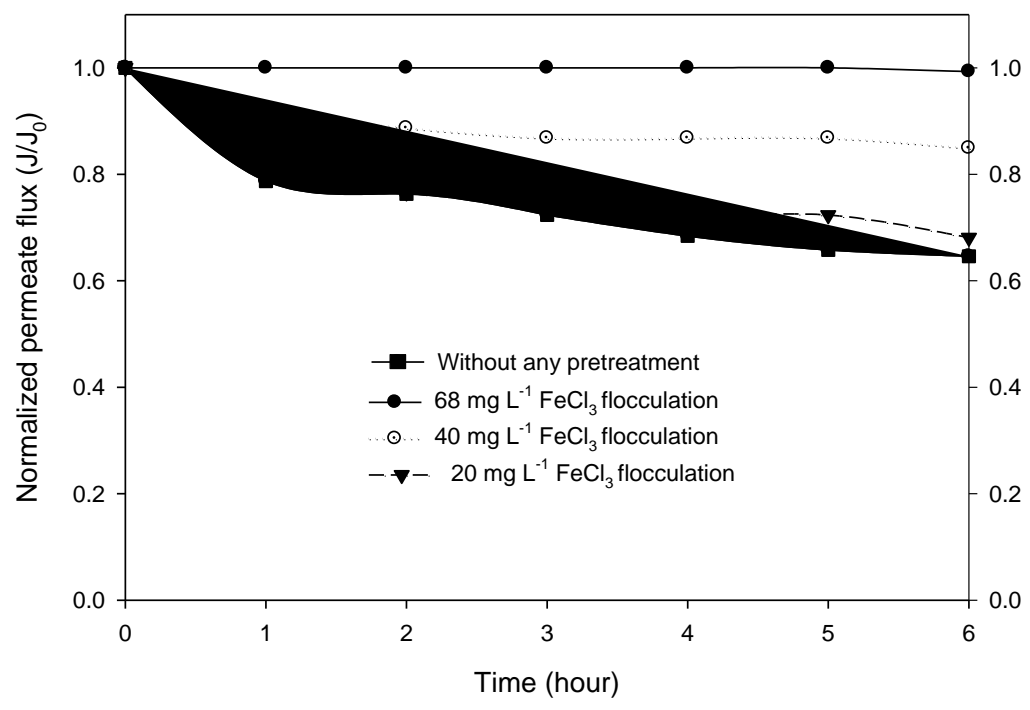

Figure 3 Temporal variation of filtration flux of UF after a pretreatment of flocculation at different $\mathrm{FeCl}_{3}$ doses (NTR 7410 UF membranes, $\mathrm{J}_{0}=1.84 \mathrm{~m} / \mathrm{d}$ at $300 \mathrm{kPa}$; crossflow velocity $=0.5 \mathrm{~m} / \mathrm{s} ;$ MWCO of 17,500 daltons; Reynold's number: 735.5; shear stress: 5.33 $\mathrm{Pa})$ 

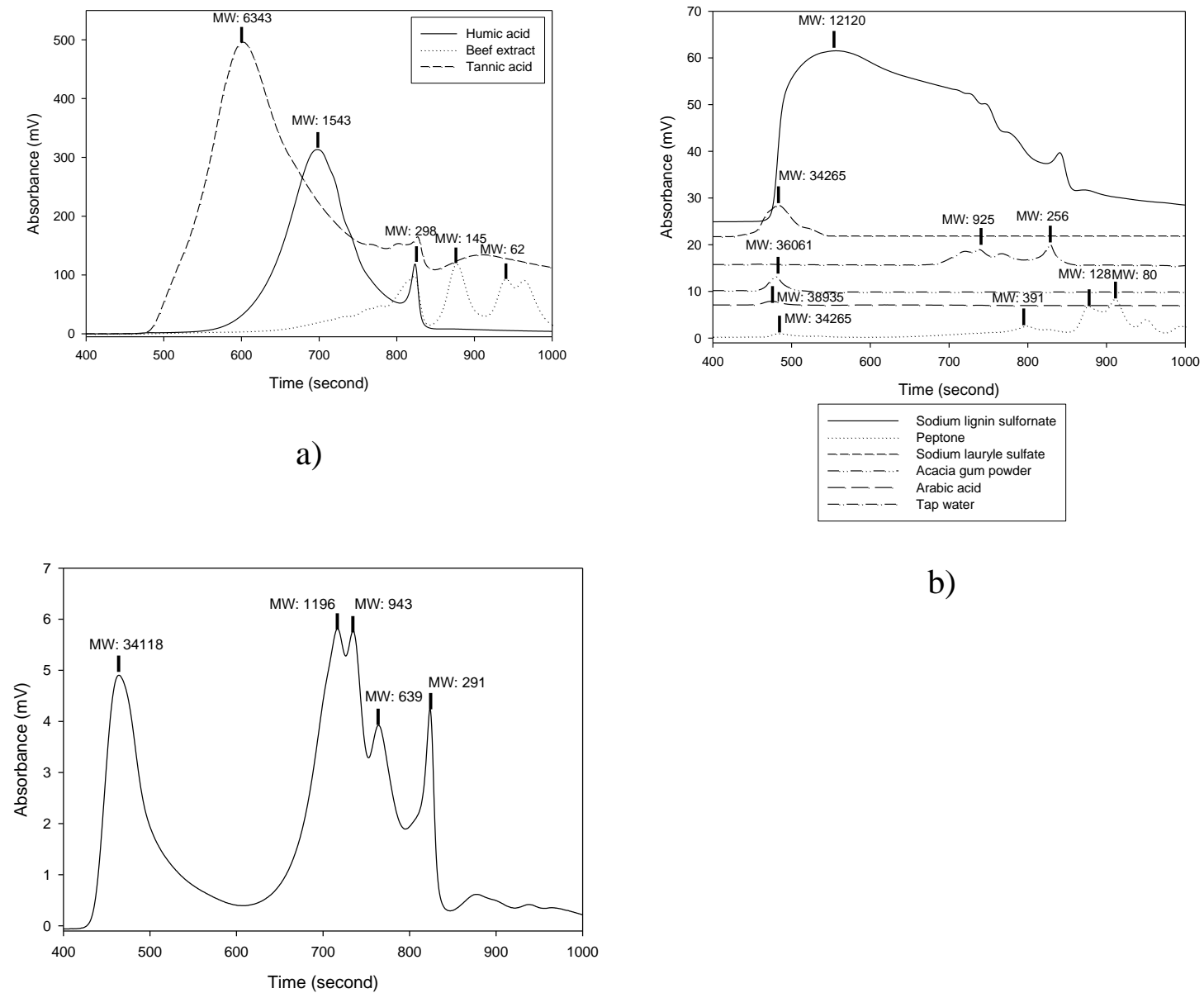

b)

c)

Figure 4 MW distribution of SOM in the synthetic wastewater (a), b): individual components in the wastewater; c) wastewater (with all compounds mixed together) 


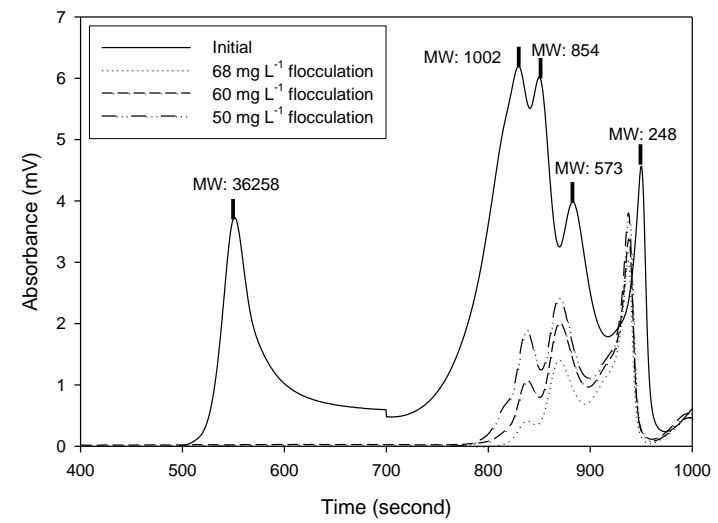

a)

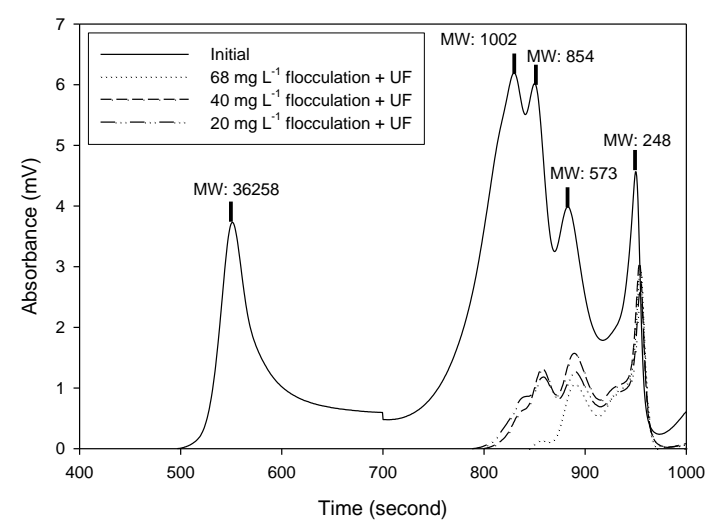

c)

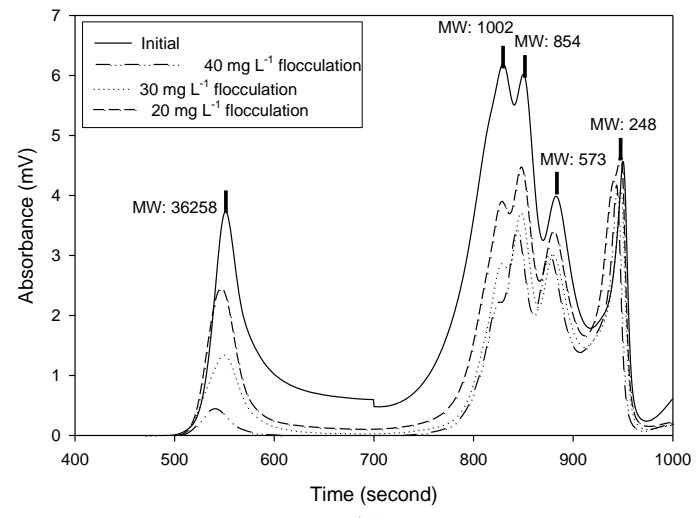

b)

Figure $5 \mathrm{MW}$ distribution of the effluent of flocculation $\left(\mathrm{J}_{0}=1.84 \mathrm{~m} / \mathrm{d}\right.$ at $300 \mathrm{kPa}$; crossflow velocity $=0.5 \mathrm{~m} / \mathrm{s} ; \mathrm{MWCO}=17,500$ daltons; Reynold's number.: 735.5 ; shear stress: $5.33 \mathrm{~Pa}$; a) MW distribution of $\mathrm{SOM}$ with higher doses of $\mathrm{FeCl}_{3}\left(50-68 \mathrm{mg} \mathrm{L}{ }^{-1}\right)$; b) with $\mathrm{FeCl}_{3}$ of lower doses (40 - $20 \mathrm{mg} \mathrm{L}^{-1}$ flocculation); c) flocculation followed by UF 


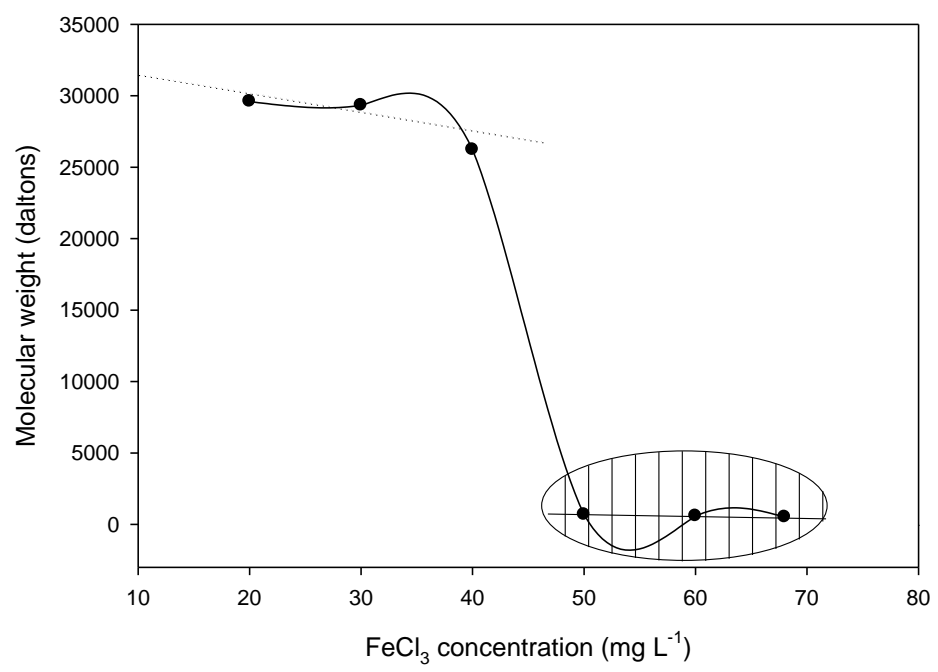

Figure 6 Correlation between the $\mathrm{FeCl}_{3}$ concentrations and the corresponding weightaveraged MW values in the flocculated effluent. 